\title{
Penerapan Multimedia dalam Pembelajaran bagi Guru di TK Aisyiyah Ranting Parangtambung
}

\author{
Veronika Asri Tandirerung ${ }^{1}$, Hasanah $^{2}$ \\ ${ }^{1,2}$ Fakultas Teknik, Universitas Negeri Makassar
}

\begin{abstract}
The community partnership program implemented in Aisyiyah Kindergarten aimed to improve the competence of kindergarten teachers in the application of multimedia learning. The existence of technological changes, as well as changes in student generation are of concern to all educators so that they can also improve and change the learning model that has been applied. The activities applied to improve the competence of teachers in Aisyiyah Kindergarten were: a) Trainedthe Kindergarten teachers to find out the method of using ICT in learning; b) Trainedthe teacher groups to skillfully plan ICT-based learning for PAUD children. The activity was conducted in Manuruki Street, Tamalate District. The implementation methods used were the lecture method and practice. The teachers were given knowledge about learning models for millennial generations and the Alpha generation. Furthermore, they were offered practical activities, including making slide presentations in Microsoft power point and creating the media for audio video providers, namely media-based website or youtube.com. The observation results of the program implementation showed high interest of teachers to learn and actively ask questions in the training process. Thus, this community service partnership program could help in improving the quality of the learning process.
\end{abstract}

Keywords: ICT learning, multimedia, Alpha generation

\section{PENDAHULUAN}

Peranan dan fungsi Teknologi Informasi dan Komunikasi (TIK) dalam bidang pendidikan sangat penting untuk pengembangan mutu pendidikan. Di era modern saat ini, diharapkan pembelajaran yang inovatif dan kreatif dengan memanfaatkan teknologi. Pengetahuan akan teknologi yang berkembang saat ini akan mengoptimalkan pemanfaatan TIK dalam pembelajaran (Batubara \& Delila, 2017).

Banyak media yang dapat digunakan dalam pembelajaran PAUD. Dari sekian banyak media yang dapat digunakan di lembaga PAUD, film animasi merupakan salah satu media pengajaran hasil IT yang dapat digunakan untuk membantu dalam meningkatkan minat belajar anak.Film animasi merupakan media yang menyajikan pesan audiovisual dan gerak. Oleh karenanya, film memberikan kesan yang impresif bagi penontonnya. Media film ini pada umumnya disenangi oleh anakanak karena karakter gambar animasi yang menarik. Hamalik mengemukakan bahwa kelebihan penggunaan film animasi dalam proses pembelajaran dapat melengkapi pengalaman-pengalaman dasar dari anak ketika bercakap-cakap, tanya jawab dan Iain-lain, menggambarkan suatu proses secara tepat yang dapat disaksikan secara berulang-ulang bila dipandang perlu. Serta mendorong dan meningkatkan motivasi anak dalam menanamkan sikap dan segi-segi afektif lainnya. Gambar-gambar dan suara yang muncul pada film yang menampilkan tayangan cerita dalam bentuk animasi kartun juga membuat anak tidak cepat bosan, sehingga dapat merangsang anak mengetahui lebih jauh lagi serta anak-anak didorong untuk mengenal dan mengetahui manfaat teknologi, sekaligus merangsang minat mereka untuk belajar dan antusias terhadap cerita yang ditayangkan pada film animasi khususnya pada proses pembelajaran yang menunjang pendidikannya. Dengan kesiapan jiwa anak peserta didik dalam menerima perkembangan pembelajaran yang berbasis TIK akan mempermudah pemahamannya. Penggunaan Information and Communication Technology (ICT) hendaknya sesuai dengan kapasitas usia peserta didik sesuai dengan perkembangan pikologisnya. Berdasarkan kenyataan bahwa pada dasarnya pengaruh 
teknologi terhadap peserta didik memang sangatlah mudah berkembang maka perlu pendidikan berkarakter agar bisa membantu proses pembelajaran sesuai dengan umur peserta didik (Heinich, 1996).

Adapun yang berkaitan dengan model pembelajaran yang berdasarkan TIK sangatlah beperan dalam kelangsungan hidup masa mendatang. Kecerdasan intelektual bukanlah sebab mendasar dalam membangun peradaban, karena peradaban sangat mempengaruhi pemanfaatan dari perkembangan pembelajaran yang berbasis TIK untuk memaksimalkan dan membangun peradaban, maka satu-satunya alasan yang rasional dan universal adalah faktor karakter.

Untuk menyediakan TIK dalam PAUD yang layak anak perlu memperhatikan kesehatan dan keselamatan anak. TIK yang digunakan memperhatikan perkembangan anak. Selain itu pula TIK dalam PAUD memperhatikan waktu yang singkat (10-20 mnt (3thn), $40 \mathrm{mnt}$ (8thn)), serta peralatan dan ruang yang cocok bagi anak.

\section{METODE PELAKSANAAN}

Berdasarkan masalah-masalah yang dikemukakan diatas, maka solusinya adalah sebagai berikut:

a. Melatih guru TK untuk mengetahui metode penggunaan TIK dalam pembelajaran bagi PAUD.

b. Melatih kelompok guru untuk terampil merencanakan media pembelajaran berbasis TIK bagi PAUD.

Program ini disusun secara sistematis pada alur kerja dengan pendekatan sebagai berikut:

a. Pendekatan partisipatif

Dilakukan secara koordinatif, melibatkan Tim PelaksanaDosen dengan Mitra.

b. Pendekatan konseptual

Dilakukan dengan pola pembinaan sikap dan mental guru TK di wilayah mitra dengan Achievement Motivation Training (AMT). Harapannya guru TK di wilayah mitra memiliki kesadaran tinggi, sikap mental positif, motivasi tinggi, semangat, dan kepercayaan diri untuk sukses sebagai pendidik di abad 21 untuk mencetak generasi penerus bangsa yang unggul dan kompetetif.

c. Pendekatan teori dan praktik

Dilakukan melalui kegiatan pembelajaran, tatap muka dan penugasan baik teori maupun praktik.

d. Pendekatan reflektif

Dilakukan dengan evaluasi kegiatan selanjutnya dilakukan refleksi dan keberlanjutan dalam bentuk monitoring dan pendampingan, baik terprogram maupun insidental guna menjaga kualitas hasil kegiatan serta meningkatkan kemitraan.

Metode pelaksanaan dalam kegiatan ini adalah dengan melakukan pelatihan pembuatan media pembelajaran kepada guru TK Aisyiyah, Parang Tambung. Untuk mengatasi permasalahan yang sudah dikemukakan di atas, maka metode utama yang ditempuh dalam kegiatan ini adalah metode ceramah, diskusi dan latihan-latihan.

Metode pelaksanaan dalam kegiatan ini adalah dengan melakukan pelatihan penggunaan media TIK dalam pembelajaran anak PAUD di TK Aisyah, Manuruki, Tamalate.

Untuk mengatasi permasalahan yang sudah dikemukakan di atas, maka metode utama yang ditempuh dalam kegiatan ini adalah metode ceramah, diskusi dan latihan-latihan.

a. Metode ceramah dan diskusi

Metode ini digunakan sewaktu menyajikan materi TIK. Dalam penyajian dengan metode tersebut, digunakan media komputer. Penyajian materi diselingi dengan tanya-jawab.

b. Metode latihan

Metode ini dipakai dalam rangka melakukan praktik cara memanfaatkan TIK, mulai dari pengaksesan internet, download, gambar animasi, video, edit dan pembuatan persentasi, ini dilakukan berkali-kali kemudian dilakukan sendiri oleh peserta pelatihan. Kemampuan peserta pelatihan dievaluasi dengan mengevaluasi produk media pembelajaran yangsudah diujikan melalui presentasi langsung setiap guru-guru TK Aisyah, Manuruki, Tamalate. 
Langkah-langkah yang ditempuh dalam pelatihan ini adalah sebagai berikut:

a. Ceramah tentang pembelajaran bagi anak TK dan media pembelajaran yang dapat digunakan.

b. Microsoft Power Point (presentasi), berguna untuk membuat media pembelajaran bagi guru, media untuk presentasi guru.

c. Cara mencari dan mendownload media audio, video atau film animasi dari youtube.

d. Evaluasi di lokasi untuk mendampingi guru dalam peningkatan kompetensi yang diperoleh melalui program yang telah dilaksanakan.

e. Penyusunan laporan.

f. Seminar akhir.

\section{HASIL DAN PEMBAHASAN}

Pelaksanaan kegiatan bertempat di TK Aisyiyah, Jalan Manuruki, Kecamatan Tamalate. TK ini berjarak $\pm 3 \mathrm{~km}$ dari Fakultas Teknik Universitas Negeri Makassar. Dalam pelaksanaan pengabdian ini, diawali dengan ceramah bahwa anak usia dini belajar dengan caranya sendiri karena kepribadian mereka belum bisa diatur secara maksimal. Jadi kesabaranlah yang harus diutamakan. Untuk belajar saja biasanya anak merasa cepat jenuh. Karena lebih menyukai bermain dan hal-hal yang menyenangkan. Dengan mengubah mindset belajar dengan menggunakan hasil teknologi komunikasi dan informasi Pendidikan seperti penggunaan gambar-gambar animasi diharapkan anak bisa menikmatinya serta memperagakannya. Anak biasanya suka melihat gambar-gambar bergerak daripada gambar-gambar diam, bahkan sering menirukan gaya dan suaranya, contoh saja upin ipin, spongebob, dan lain-lain.

Pakar pendidikan Mark Prensky dalam Mardiana (2011) mengemukakan ada dua generasi yaitu digital natives dan digital immigrants. Digital natives merupakan generasi yang lahir pada era digital, sedangkan digital immigrants adalah generasi yang lahir sebelum era digital. Generasi digital natives lebih banyak mengisi kehidupan dengan penggunaan komputer, video games, digital music players, video cams, cell phone dan berbagai macam perangkat permainan yang diproduksi di abad digital. Generasi digital natives sudah terkondisikan dengan lingkungan seperti itu dan mengganggap teknologi digital sebagai bagian yang tidak terpisahkan dari kehidupannya. Ratarata generasi digital natives ketika lahir sudah berada dalam lingkungan teknologi digital.

Guru TK saat ini menghadapi anak-anak yang merupakan generasi Alpha, generasi yang lahir mulai tahun 2010. Menurut Mark McCrinddle (Awaludin, 2014), generasi Alpha adalah generasi yang paling dekat dengan internet. Generasi ini dilahirkan dari generasi $\mathrm{X}$ dan generasi $\mathrm{Y}$. Oleh karena itu, guru-guru TK saat ini perlu menyadari perkembangan dan kebutuhan dari anak-anak yang dihadapinya saat ini.

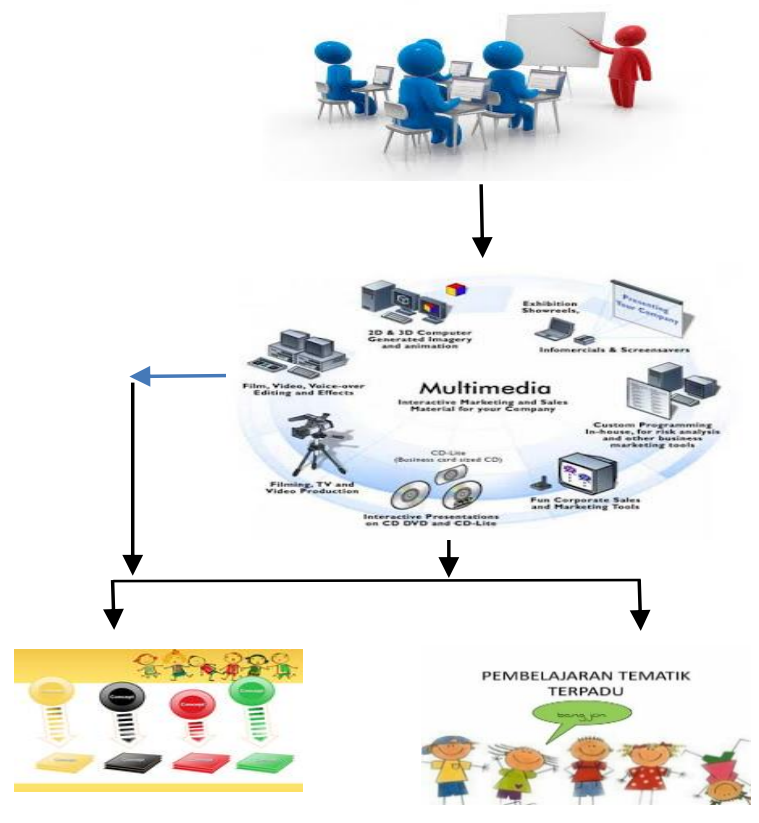

Gambar 1. Gambaran IPTEK yang ditransfer

Pelaksanaan program ini dilaksanakan dengan menggunakan metode ceramah dan praktik. Tabel 1 menunjukkan jenis kegiatan dan program yang dilaksanakan.

Jenis media yang dapat digunakan dalam pembelajaran yaitu:

1. Media visual meliputi gambar, sketsa, diagram, charts, grafik, kartun, poster, peta dan globe.

2. Media dengar meliputi radio, magnetic, tape recorder, magnetic sheet recorder, laboratorium bahasa.

3. Projected still media meliputi slide, film strip, over head projector, micro film, mcro projector. 
4. Projector motion media meliputi film, TV, close circuit television (CCTV), video tape recorder, computer.

Tabel 1. Kegiatan transfer Iptek

\begin{tabular}{cl}
\hline Kegiatan & \multicolumn{1}{c}{ Program } \\
\hline Ceramah & $\begin{array}{l}\text { Teori tentang pembelajaran generasi } \\
\text { Milenial dan generasi Alpha }\end{array}$ \\
\cline { 2 - 2 } & Pengenalan Media Pembelajaran \\
\hline Praktik & $\begin{array}{l}\text { Praktik mencari bahan ajar berbasis } \\
\text { audio video }\end{array}$ \\
\cline { 2 - 2 } & $\begin{array}{l}\text { Cara Mendownload dan menyimpan } \\
\text { bahan ajar berbasis audio video }\end{array}$ \\
\hline
\end{tabular}

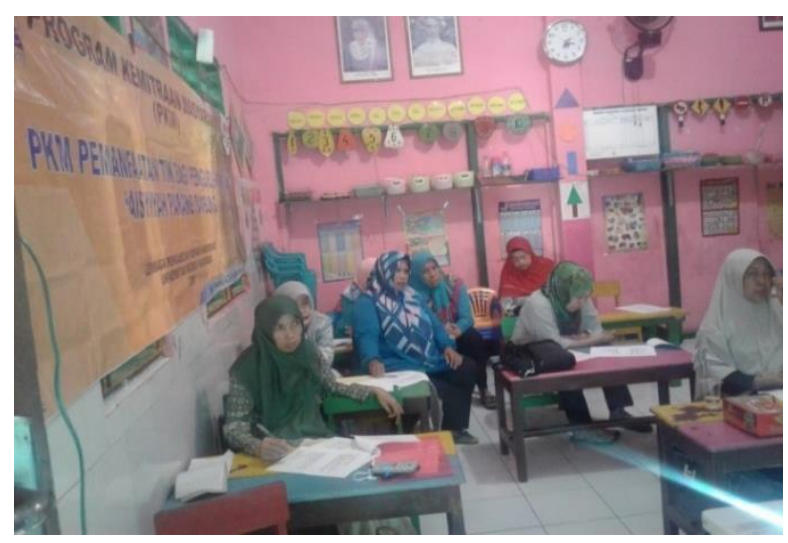

Gambar 2. Pelaksanaan kegiatan

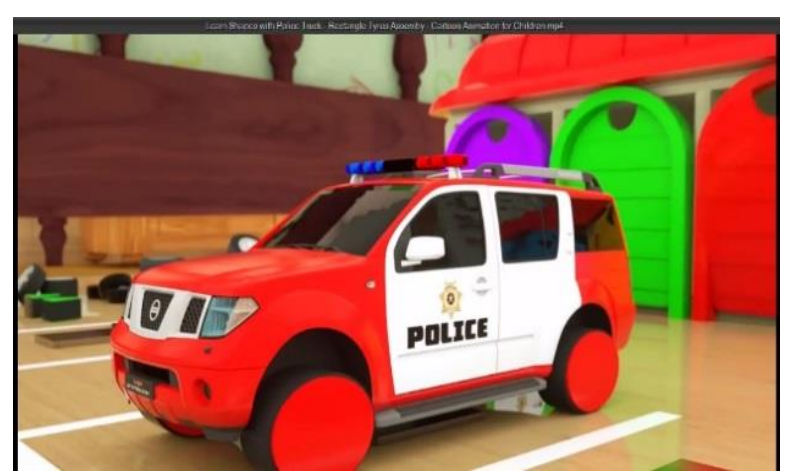

Gambar 3.Contoh model pembelajaran bentuk-bentuk benda berbasis video animasi

Menurut Zakiah Dradjad, alat atau jenis-jenis media dikelompokkan yaitu:

1. Alat pendidikan yang bersifat benda.

a. Media tulis, seperti buku.

b. Benda-benda alam seperti manusia, hewan, tumbuh-tumbuhan dan sebagainya. c. Gambar-gambar yang dirancang seperti grafik.

d. Gambar-gambar yang di proyeksikan, seperti video transparan.

e. Audio recorder (alat untuk mendengar), seperti kaset, tape radio.

2. Alat media yang bukan bersifat benda.
a. Keteladanan.
b. Perintah atau larangan.
c. Ganjaran dan hukuman.

\section{KESIMPULAN}

a. Pelaksanaan kegiatan dilaksanakan di TK Aisyiyah tepatnya di Jl.Manuruki Kecamatan Tamalate. Jarak dari Fakultas Teknik $\pm 3 \mathrm{Km}$. Dengan demikian, kehadiran Universitas Negeri Makassar dapat dirasakan lebih nyata bagi guru sebagai tenaga kependidikan. Guru sangat bersemangat mengikuti pelatihan ini dan mengharapkan adanya kegiatan berkelanjutan untuk meningkatkan kompetensi guru.

b. Teori pembelajaran yang disampaikan dengan metode ceramah telah menambah ilmu dan pemahaman guru dan dari hasil pengamatan selama proses pelaksanaan kegiatan, peserta sangat berminat dan antusias serta aktif dalam bertanya.

c. Media pembelajaran yang disampaikan meliputi media persentasi yaitu power point, serta media untuk mencari dan mendownload bahan ajar berbasis audio video yaitu melalui website youtube.com.

\section{UCAPAN TERIMA KASIH}

Terima kasih kepada Universitas Negeri Makassar yang telah mendanai kegiatan pelaksanaan pengabdian kepada masyarakat ini. Terima kasih kepada kepala Yayasan TK Aisyiyah yang telah memfasilitasi kegiatan. 
Penerapan multimedia dalam pembelajaran ....

\section{DAFTAR PUSTAKA}

Awaludin, Wahyu. 2011. Mengenal Generasi Alpha. (Online), (https://www.selasar.com/kreatif/ mengenal-generasi-alpha.

Batubara, Delila Sari. (2017). Kompetensi Teknologi Informasi dan Komunikasi Guru SD/MI (Potret, Faktor-faktor, dan Upaya Meningkatkannya). Jurnal Muallimuna (48-65). ISSN 2476-9703, Vol 3.No 1, Oktober.
Heinich, Robert. (1996). Instructional media and technologies for learning. New Jersey: Englewood Cliffs, Prentice-Hall,Inc.

Mardiana, Riana. 2011. Potensi Digital Natives dalam Representasi Literasi Informasi Multimedia Berbasis Web di Perguruan Tinggi.http://journal.ipb.ac.id/ index.php/jpi/article/view/5264). 